\title{
THE MIXED ECONOMY
}

It is well known that all Western economies are now mixed economies. What is less well known is why they have opted for a system of mixed ownership, partly State, partly private. This book seeks to provide theoretical justification for that system and to illustrate it with examples drawn from a wide range of areas of economic life and policy. Thus Aubrey Silberston discusses the role of the British Steel Corporation in a mixed economy, Robert Millward seeks to compare the performance of public and private enterprise, and Charles Rowley looks at industrial policy in the mixed economy.

Anthony Culyer considers health services and George Psacharopoulos examines education; David Howell looks at energy and Andrew Bain at finance; Roy Hattersley seeks to situate the mixed economy in its political context, Brian Hindley and Derek Ezra to situate it in its world context, and Maurice Peston to construct a theoretical case for an inescapable condition. In his introduction and in his own contribution Lord Roll of Ipsden ties the threads, analytical and descriptive, together, and indicates important guidelines for future thinking and research. 
Recent Section F publications include the following

Roy Jenkins (editor) BRITAIN AND THE EEC Jack Wiseman (editor) BEYOND POSITIVE ECONOMICS? M. Gaskin (editor) THE POLITICAL ECONOMY OF TOLERABLE SURVIVAL

W. Beckerman (editor) SLOW GROWTH IN BRITAIN

E. Nevin (editor) THE ECONOMICS OF DEVOLUTION

W. Leontief (editor) STRUCTURE, SYSTEM AND ECONOMIC POLICY 


\section{THE MIXED ECONOMY}

Proceedings of Section F (Economics)

of the British Association for the Advancement of Science, Salford 1980

\section{Edited by \\ Lord Roll of Ipsden}

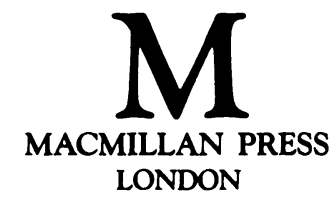


(C) the British Association for the Advancement of Science 1982

All rights reserved. No part of this publication may be reproduced or transmitted, in any form or by any means, without permission

First edition 1982

Reprinted 1984

Published by

THE MACMILLAN PRESS LTD

London and Basingstoke Companies and representatives throughout the world

ISBN 978-0-333-37276-0

ISBN 978-1-349-07419-8 (eBook)

DOI 10.1007/978-1-349-07419-8 


\section{Contents}

Notes on the Contributors vi

Introduction ix

1 The Mixed Economy Lord Roll of Ipsden 1

2 The Nature and Significance of the Mixed Economy $\begin{array}{ll}\text { Maurice Peston } & 18\end{array}$

3 Industrial Policy in the Mixed Economy Charles Rowley 35

4 The Comparative Performance of Public and Private Ownership Robert Millward $\quad 58$

5 Steel in a Mixed Economy Aubrey Silberston 94

6 Politics and the Mixed Economy Roy Hattersley 113

7 Health Services in the Mixed Economy A. J. Culyer 128

8 Education and Society: Old Myths versus New Facts George Psacharopoulos 145

9 Energy Policy and the Mixed Economy David Howell 162

10 Finance in the Mixed Economy Andrew Bain 175

11 The Mixed Economy in an International Context Brian $\begin{array}{ll}\text { Hindley } & 187\end{array}$

12 The Mixed Economy and British Trade Lord Ezra 206

$\begin{array}{ll}\text { Index } & 224\end{array}$ 


\section{Notes on the Contributors}

Lord Roll of Ipsden is a merchant banker and Chairman of S.G. Warburg and Co. Ltd and its holding company, Mercury Securities Ltd, a director of Times Newspapers Ltd and of other companies. He has been a Civil Servant, retiring in 1966 from the post of Permanent Under-Secretary, Department of Economic Affairs, as well as having been an academic - he was a Professor in Economics at Hull University. Among his books are $A$ History of Economic Thought and Uses and Abuses of Economics.

Maurice Peston is Professor of Economics at Queen Mary College, University of London. He is the author of Theory of Macroeconomic Policy (1974) and Whatever happened to Macroeconomics (1980). He has been a special adviser to the Secretaries of State for Education and Science and Prices and Consumer Protection.

Charles Rowley, B.A., Ph.D., graduated from the University of Nottingham with first class honours in 1960 and a Ph.D. in 1964. He has been a lecturer at Nottingham and Kent and a senior lecturer at Kent. He has also been a reader at the University of York. Since 1972 he has been David Dale Professor of Economics at the University of Newcastle upon Tyne. He has published in the fields of welfare economics, public economics and industrial economics.

Robert Millward is Professor of Economics and Chairman of the Department of Economics at the University of Salford, Lancashire. $\mathrm{He}$ is the author of Public Expenditure Economics (1970) and of several articles in the field of public finance. His recent interests have extended to problems of economic organisation, including the economics of long-run institutional change in European economic history. $\mathrm{He}$ also recently served as a member of the Severn Barrage Committee of the Department of Energy.

Aubrey Silberston is Professor of Economics at Imperial College, London. $\mathrm{He}$ is co-author of books on the motor industry, the patent 
system and the steel industry, and has published a number of articles on the economics of industry. He was a member of the Monopolies Commission 1965-8, of the Royal Commission on the Press 1974-7, and a part-time board member of the British Steel Corporation 1967-76.

Roy Hattersley is the Deputy Leader of the Labour Party and Member of Parliament for the Sparkbrook division of Birmingham. He has been Labour Party spokesman on Defence and on Education and Science and was Secretary of State for Prices and Consumer Protection from 1976-1979. He was a Visiting Fellow at the Institute of Politics at Harvard University in 1971 to 72.

Anthony Culyer is Professor of Economics and Deputy Director of the Institute of Social and Economic Research at the University of York. He has contributed many articles to economics and other journals and his recent books include Need and the National Health Service (1976), Measuring Health: Lessons for Ontario (1978) and The Political Economy of Social Policy (1980). He is co-editor of the new Journal of Health Economics, and is an economic adviser to several government and international agencies.

George Psacharopoulos is a lecturer in economics at the London School of Economics and Political Science. He is the author of $R e$ turns to Education (1973), Earnings and Education in OECD Countries (1975) and several journal articles on the economics of education and manpower planning.

David Howell, Conservative Member of Parliament for Guildford, was Secretary of State for Energy and a member of the Cabinet until June 1983. He served previously as Secretary of State for Transport. $\mathrm{He}$ is the author of many articles and pamphlets, was formerly on the editorial staff of the Daily Telegraph and before that in the economic section of the Treasury.

Andrew Bain is Walton Professor of Monetary and Financial Economics at the University of Strathclyde. He was a member of the Committee to Review the Functioning of Financial Institutions, and is the author of The Control of the Money Supply (3rd edn, 1980) and The Growth of Television Ownership in the United Kingdom (1964), and joint author of Company Financing in the United Kingdom (1976). 
Brian Hindley is a Senior Lecturer in Economics at the London School of Economics and Counsellor for Studies of the Trade Policy Research Centre. He has published widely in the areas of trade policy and industrial policy and, most recently, 'Voluntary Export Restraints and Article XIX of the General Agreement on Tariffs and Trade', which appears in Current Issues in Commercial Policy and Diplomacy (Macmillan, 1980), edited by John Black and Brian Hindley.

Lord Ezra is a former Chairman of the National Coal Board. In May 1978 he published a book entitled Coal and Energy. He has also written numerous articles and broadcasts on subjects associated with energy, economic and industrial affairs, overseas trade and the problems of management. 


\section{Introduction}

All Western industrial nations have had mixed economies for many years. What is new is an acute debate concerning that mix and the breakdown of consensus with respect to the precise balance between the public and private sectors - in the limit between the command state and the night watchman state. When Section F of the British Association met in Salford in September 1980 to discuss the size, performance, composition and future of the mixed economy, it was doing so at a time of an apparent polarisation of attitudes as between left-wing collectivists and right-wing free marketeers. In that sense Section $F$ was discussing not only the mixed economy but the compromise on which British economic policy had been based throughout the postwar period.

In the circumstances, it would be surprising if all the contributors to the discussions were in agreement on all the issues. Nor were they expected to be, for the purpose of an academic gathering such as the annual meeting of Section $\mathrm{F}$ is rather to air ideas than to arrive at decisive solutions. Nonetheless, the papers brought together in this volume do draw our attention to certain key topics in which the interest of all the contributors is engaged. Chief among these are the following:

Firstly, efficiency. Professor Millward makes clear how difficult it is to compare the performance of enterprises publicly-owned with that of enterprises in the public sector. In his paper, eschewing comparisons based on profitability (since governments have used public enterprises as instruments for the attainment of other policy objectives than profit maximisation alone, notably price stability), he opts instead for comparisons based on the relative cost-efficiency of public and private firms which supply the same product. Cases in point are not often found in the UK and the bulk of the evidence which he cites is drawn from the USA, Canada, Australia and Switzerland. His conclusion is that management in private enterprise would appear to be less costefficient than it is in the public sector (the exception seems to be refuse collection). A comparison based on relative profitability might, of 
course, yield different results, although the studies on the US electric power industry to which Professor Millward refers illustrate a case where the average rate of return in the state sector does not in practice differ widely from that in private enterprises. Professor Culyer, looking at the health services, returns a verdict similar in its positive attitude towards social provision: he argues that a national health service - contrary to much traditional economic analysis - is actually a more rational mode of organising health care services than would be a private system.

It would be wrong to discuss managerial efficiency in the mixed economy without considering that of politicians and bureaucrats as well. This topic is taken up by Professor Rowley. He draws attention to recent developments in political economy which call into question the omniscience and neutrality of governments and reminds the reader that government failure (a phenomenon less frequently discussed in the literature than is market failure) might result from the distortion of information flows on the part of self-seeking pressure groups and growth-conscious bureaucracies. He shows how state regulation (in the form of, say, tariffs or employment protection laws) may have the effect of ensuring rents to producers at the cost of consumers compelled as a result of the measures to pay supercompetitive prices; and he describes how vote-seeking politicians may have a perhaps unwelcome bias towards deficit finance and excessive expansion of the money supply. He also argues (in contrast to behavioural theorists who deny that market forces adequately discipline organisation men) that, in the perspective of agency theory, the market value of the manager himself is derivative from the performance of the firm he manages.

Professor Silberston, in his paper on the British Steel Corporation (of which he himself was a part-time board member from 1967 to 1976) takes up the theme of performance and politics. He acknowledges that the BSC has in the past failed on occasion to satisfy an unexpectedly high level of demand for steel and that it did not in its early years lay sufficient stress upon initiative and productivity. He blames politicans in part for these shortcomings - for intervening in investment and pricing policies, for example; for retarding closures which were in actual fact inevitable (notably those of works which were suboptimal in scale and employed obsolete technology); for placing excessive demands upon the valuable time of top management. He points out in addition that the very fact that the BSC was nationalised enabled trade unions to impose overmanning and high pay on the or- 
ganisation in the knowledge that it - unlike its competitors in the private sector - was unlikely to be allowed to go bankrupt. At the same time, he also emphasises BSC's successes in the R and D field and its demonstrated ability to exploit economies of large scale.

The BSC faces competition from abroad: even if there were not significant private sector production, it is no more a natural monopoly than the National Coal Board, British Airways, British Shipbuilders, or British Leyland. The deleterious effects of privately-owned natural monopolies have often supplied an easy explanation of why industries are nationalised; and its unavailability in the case of industries producing internationally traded goods raises the issue of what policy goals, and what interests, nationalisation of such industries is intended to serve. Dr Hindley notes that nationalisation and nationalised industries have been used as means of protecting domestic industries against foreign competition; but he also argues that policy produces rough counterparts of these protective practices when privately-owned industries are pressed by imports. He therefore views these policies of nationalised industries as part of a wider problem, which is the unwillingness of many industrialised countries to adjust to changes in comparative costs. He suggests that protective policies in either the public or private sectors are designed to maintain or increase real wage rates in industries subject to international competition, and he concludes that the very extent of these policies (which some advocate should be further extended) makes it most unlikely that that aim can be achieved.

No one, as it happens, would say that public enterprise is unaware of the international dimension; and in his paper the Chairman of the National Coal Board, Sir Derek Ezra, draws attention to a little-noted contribution made by the nationalised industries - one independent of export performance and import substitution - to the balance of payments. This contribution is the sale of British technical expertise through consultancy and project-management schemes abroad; through the training of overseas personnel in the use of British equipment; and through the pooling and sharing of information with other nationalised industries at home.

Secondly, equity. A democratic society does not wish merely to attain its chosen economic objectives with no more than the minimal expenditure of scarce resources, it wishes also to do so in a manner fully consistent with generally accepted notions of fairness and social justice.

Justice is the theme of Dr Psacharopoulos' paper on education. He 
notes the high private rate of return to investment in human capital in all countries and, rejecting the market segmentation hypothesis, presents statistical evidence in support of the thesis that the provision of education to an otherwise poorer man will enable him in practice to receive greater lifetime earnings, even if he is in the short run subject to some graduate unemployment while waiting for a job. He notes that differentials for skill appear to be constant over long periods, suggesting that demand rises at the same time and rate as the supply of educated manpower. Every additional year of schooling brings with it incremental earnings; and, while the benefit is particularly great for the child schooled in the private sector of education, in all cases the provision of education contributes more to life chances than does family background.

Fairness extends beyond the scarce resource of money to spend on goods and refers as well to the whole institutional environment within which that money is earned. This is the essence of Roy Hattersley's contribution. $\mathrm{Mr}$ Hattersley calls for an increase in the number of autonomous, socially-owned companies, giving workers via collective ownership a vested interest in the economic success of their organisation; and argues that employee involvement, not state direction, is the way to harness enthusiasm and morale and thus to improve the performance of British industry. Mr Hattersley's paper - which seeks to show that self-interest and democratic socialism are not incompatible was written at the very time that workers at Gdansk and Stettin were demonstrating their conviction that central ownership and bureaucratic control are not always and everywhere perceived to guarantee personal liberty and social equality.

Mr Hattersley is evidently convinced that competition is an important part of the just economy, and he joins his voice to several others in this volume in advocating effective restrictive practices legislation aimed at preventing undesirable concentration of economic power. $\mathrm{He}$ in addition proposes interventionist measures of a positive nature measures such as regional policy or the provision of funds for industry. Clearly, he would be in agreement with Professor Peston's point that private economic transactions have public consequences; that property is to some extent held in trust; and that responsibility to the community cannot be neglected in any discussion of economic arrangements and regulations.

Thirdly, flexibility. An economic process is a dynamic, not a static thing. It is in good measure to be judged by how well it adjusts to unforeseen shocks. One of the most challenging tests in recent years has 
been the situation in the energy field since 1973, and the paper by the Secretary of State for Energy, Mr David Howell, is particularly illuminating in its attempt to present a Conservative case for rationing via the price mechanism. The market, he argues, encourages energy conservation, say, via home insulation, or via the substitution of the fuel-efficient vehicle for the huge 'gas guzzler', and the search for new sources of power. He adds, however, that a policy of market-determined energy prices must be accompanied by a degree of compassion towards those individuals and groups poorly placed to adapt quickly, together with government support to research and development schemes in areas as yet too risky to make them commercially viable. $\mathrm{Mr}$ Howell does not say that market signals are perfect guidelines along the road to change, but he is convinced that central planning would lead to worse errors.

Another illustration of flexibility is macroeconomic flexibility, the theme of Professor Bain's paper. He points out that, while publiclyowned financial intermediaries are in the UK the exception rather than the rule, they are nonetheless key participants in the mixed economy by virtue of their role in the process of credit creation. Although there is some uncertainty as to the sensivity of private-sector investment to small changes in rates of interest, there can be no doubt that the public sector is significantly less sensitive than is the private to the cost factor in the short run. Professor Bain's general opposition to narrowlydefined monetary targets on the grounds that they impede capital market flexibility is likely to prove particularly controversial.

Policies to foster macroeconomic flexibility have in recent decades become an important part of social regulation; and it is interesting that several papers in this volume favour incomes policy as opposed to the invisible hand when dealing with cost inflation and highly imperfect labour markets.

The mixed economy was not built to the specification of an architect; and its justification must be sought not in any fundamentalist doctrine, but in its responsiveness to the highly complex variety of objectives of man in society. This book does not seek to advocate any particular pattern of a mixed economy, but simply to say what it is and does and what it might in the future become. 